\title{
Second In A Series: Insight From SRM's Charter Members
}

The SRM History Committee has conducted interviews with many of the Society's Charter Members to capture their perspectives of events leading to and subsequent to the formation of the American Society of Range Management in 1947-48. Interviews from several of these individuals are being shared for today's SRM members to enjoy and learn from.

\section{SRM Charter Member - Laurence E. Riordan}

Editor's Note: Interview conducted by Eddie Alford, 2002. Riordan can be reached at 6921 South Detroit St., Centennial, CO, 97034; and during the winter months at 3020 East Main, Space E12, Mesa, AZ 85213.

Having grown up on a ranch in Colorado and having a strong conservation background, Riordan found himself attending school at Colorado A \& M. After some work experience and eventual graduation, he was drafted into the Service. Finally, in January 1946 he was back to civilian life and reported to the Grazing Service office, but it no longer existed.

He tells, "The Grazing Service and the General Land Office had been combined into the Bureau of Land Management. They had no money but were supposed to have an appropriation by June or July. I was advised to find some temporary work. I contacted a friend who I had worked with in the range survey crews at Grand Junction. He informed me he had just found a job with the Colorado Fish and Game department working on deer and elk range. He said they might have a job for me. I talked with Delbert Hunter, state game manager at Denver and was hired on a Federal Aid Deer/Elk research project. In time I became head of that project. I transferred to the Denver office of Fish and Game and worked as federal aid coordinator for eight years. I then took a Civil Service exam and was appointed Deputy Director of the Department.

Riordan first learned about the formation of the Society from his alma mater A\&M. "I got a letter from the department telling me of the meeting to be held in Salt Lake City in February 1948 in which interested people would be looking at forming a professional organization. I decided to go and I joined the American Society of Range Management. We determined that the headquarters should be somewhere in the western range states. There were no Sections at first. But, it wasn't long before states began to form them. I seem to think that Utah may have been the first with Colorado close by. Don Hervey was the first Colorado Section President and I was the second. It was the year Fred Renner was ASRM President. I have been in both the $\mathrm{CO}$ and $\mathrm{AZ}$ Sections."

Overall, Riordan says he feels his expectations from SRM have been fulfilled. He points out, "There was terrible range deterioration early on in the West. Many ranchers including my own family thought conditions were due to continued drought, which of course was false. Education was an important early mission and need and the Society addressed that squarely. Also, and of high importance, was the discussion of open vs. closed membership, i.e. need for a formal education. We realized that ranchers controlled what happened on the land. One of our strengths, therefore, is our open membership policy. I think we have gone far beyond what many of us visualized. Now there is world-wide acceptance of the profession and the use of knowledge."

Asked if he thinks SRM is on the right track? Riordan says, "Yes, I do. There are still sore spots and concerns but as I travel in the West I see great improvement. Riparian areas are recovering when good management is practiced. Knowing that plants are the basis for successful range management and that their requirements must be met is the key. I'm sorry to say that I still see too closely grazed short 
grasses in places in eastern Colorado. However, the Society is trying to bring along range users. In any Society there is some internal controversy and concern. We need to recognize that the ecosystem concept still is new to some people. But, yes, we need to continue along the paths that have been set."

\section{SRM Charter Member - E. H. 'Pat' McIlvain}

Editor's Note: Interview conducted by Bob Gillen, October 2001. McIlvain can be reached at Rt. 1, Box 118, Woodward, OK 73801; Phone (580)256-2034.

In 1947-48 when SRM was getting started, McIlvain was employed at the Woodward (OK) Field Station as an agent in a full time range management position. He had taken a year off to go to Utah State at Logan and recalls he was there when the initial meetings took place so got in on the formation of the Society.

Prior to that time, he had enrolled as a forestry student at Colorado A \& M and eventually learned that one of the subsections of that profession was range management. He says, "Having grown up in Arizona and working on a ranch when I was 15,16 , 17 years old, I was interested in that phase of it. However, I did think I was going to wear hobnailed boots and jump from log to log all the rest of my life. I was employed by the university doing range survey in eastern Colorado, Elbert County, for two summers. I enjoyed it, liked it and just decided to stay in that full time. After the war, I spent four years in the service, I went to Utah State and got a Master's degree. Then I got a scholarship for a doctor's degree at University of California but I came back to work in the summer here at Woodward and have been here ever since."

He adds, "Our first job was to do line transect surveys for measurement of vegetation on the 4300 acre experimental range. We had help from Forest Service range management people. They came in and spent time with us developing procedures of line transect range survey. Following that I became interested in measuring forage production rather than basal density of plants. That is what we spent an awful lot of time doing. It was to measure benefits or results of various stocking rates, supplemental feeds, brush control through gains of yearling cattle, i.e. put out weaner steers and measure year- long gain. That was our approach to finding solutions/answers to practical problems."

About joining the Society, McIlvain says, "My boss Dave Savage at Woodward, was instrumental in formation of the Society along with Fred Renner, Joe Pechanec and the others. At Logan, my boss was Wes Keller. They were all interested in forming the Society and I was a junior member. I didn't have any question about joining. It was going to be just join up and go."

He says SRM Sections were not envisioned at that time, but remembers they were developed in about 1950. "Jack Harlan, grass breeder here at Woodward, was the first President/Chairman of the Kansas-Oklahoma Section and we just joined in and became part of it too," McIlvain says. Eventually his involvement included being on or chairman of a lot of different committees. He also held offices in the Kansas-Oklahoma Section.

McIlvain also attended the first annual meeting at Salt Lake City, and says, "Meeting the old hands that had a reputation in the field of range management, getting to shake their hands, talk with them and see the whole organization structure that was being presented was impressive."

What were McIlvain's expectations of the Society in 1948 and have they been fulfilled over the years? He says, "I got the impression real early that the mission of the Society, at least from a research standpoint and people in the field doing research of one kind or another, either intensive research or accidental research picking up good practices as they were developed, was to develop tools for range managers.

"Because I lived in the Plains here the tools were for ranchers who did manage rangelands. Then we had to get that information to the ranchers, so it was a two-pronged deal. One was to develop the tools and the second was to disseminate information so that they could manage. The first ten years of the Society that was the mission I remember most. Then we kind of drifted off into, as far as I am concerned, into a bunch of stuff that had no practical bearing for the rancher," McIlvain says.

He adds, "The range managers on the Great Plains are ranchers. I don't remember what rancher membership is now but I bet it's way below where it used to be. I'm not seeing the Society having much of an objective to correct that. We seem to be interested in environmental concerns, wildlife concerns 
and things that are not of practical help to people who are managing the range. I personally think that is the wrong direction to be going in."

In offering advice to young people considering entering the field of range management, McIlvain also says, "I wouldn't be too enthusiastic about highly recommending young people to get into the field. Range employment is very dependent on federal and state payroll. The people I am seeing in range are more interested in minor aspects of what I consider to be the most useful activity that the Society could be engaged in. I just can't get enthusiastic about young people getting into that stuff."

\section{SRM Charter Member - William Daly Hurst}

Editor's Note: In 2003 at 87 years old, Hurst recorded his history with SRM. His address at the time was Apt. 9125 Copper NE, \#222, Albuquerque, NM 87123.

These are Hurst's recollections: At the time the Society for Range Management was founded in 1948, I was with the Forest Service - USDA assigned to the Cache National Forest in Logan, Utah. I was serving as a Staff Officer to Forest Supervisor James Stewart. My duties were multi-functional but the majority of my time was devoted to Land Acquisition and Range Management, becoming deeply involved in fire control activities during the fire season.

There was a great deal of interest among Forest Service people in the proposed new Society, the American Society of Range Management. Additionally, living in Logan, Utah and being a graduate of Utah State University School of Forestry, Range and Wildlife Management, I shared the enthusiasm of those in the University's Division of Range Management for the proposed new organization. We were especially excited over being involved in an organization where other people interested in rangeland management could participate, especially those from the livestock industry. The top leadership in the Forest Service encouraged membership in the Society. A large percentage of the initial membership of the Society was made up of Forest Officers, about 38\% I believe. When I was President of the Society in 1970 about $35 \%$ of the membership came from the Forest Service.

I joined the Society as a Charter Member on May
7, 1948 In Salt Lake City, Utah. Several other men from Logan as well as from other localities in Utah joined the same day. Dues were $\$ 3.00$ per year.

I have only faint recollections of ASRM Section meetings being held in 1948 and 1949. I do remember being a member of the Utah Section. My diary says that I attended a Utah Section meeting in Salt Lake City in November 1948. It was held at the New House Hotel and lasted two or three days. I don't recall the discussions which took place but I do remember enjoying the meeting and my association with other Society members

The 1948 issue of the Journal of Range Management, which was the first issue of the Journal, states, "By the time of our first annual meeting of the Society in January 1948, 500 had joined the Society. At present there are more than 600 members." I have belonged to the Utah, National Capitol and New Mexico Sections.

At the time the Society was established the primary objective, as I viewed it, was to create a platform from which all those interested in rangeland management could as equals, address the opportunities and problems associated with the management of the native rangelands. No such platform then existed. From this perspective my expectations have been fulfilled.

I do worry some however, over the scope of our thrust. It seems that too often the domestic livestock forage value of rangelands dominate the Society's agenda with other values being slighted. I expressed this viewpoint, which is shared by others, in my address before the Society in 1971 while President of the organization. I yet hold the same opinion. I must say however, the Society gave me an opportunity to express my opinion before a very knowledgeable group of people, an opportunity that may have otherwise been denied.

I worked for the Forest Service - USDA for 39 years following my graduation from Utah State University with a degree in Forestry-Range Management. In all of my assignments Range Management has been a major activity and often a dominant one. I enjoyed working with livestock people and have many good friends in that industry. For 28 years I worked in the Intermountain Region of the Forest Service headquartered in Ogden, Utah. Positions held include Range Examiner, District Forest Ranger, Assistant Forest Supervisor, Forest Supervisor, Regional Director of the Division of 
Range and Wildlife Management and Deputy Regional Forester. I served as a member of Utah's Board of Big Game Control for ten years. For two years I was Assistant Director of the Division of Range Management in the Washington Office of the Forest Service. The last ten years of my career were spent in the Southwestern Region of the Forest Service where I served as Regional Forester stationed in Albuquerque, New Mexico. All were rewarding assignments. During my career after 1948, ASRM/SRM involvement was strongly encouraged and many Forest Officers belonged to the organization.

What sparked my interest in Range Management? Before graduating from High School in Panguitch, Utah in 1934, I was interested in a career in either Civil Engineering or Forestry, influenced I believe by my Father who was a Forester and my grandfather who was an Engineer. I began College at Utah State University in the fall of 1934 thinking of a career in Civil engineering. Job opportunities however seemed more promising in Forestry mainly due, I believe, to the vast Civilian Conservation Corp program which was putting thousands of young men to work in the Nation's forests, parks and rangelands. I therefore entered the School of Forestry. A year or two later I switched my major to Forestry-Range Management. Dr. L.A. Stoddart who established the Range Management Department in the School of forestry in 1936 swayed me in this direction.

In the Utah Section I was quite active for many years. The assignment I best remember was being Co-chairman of the Arrangements Committee for the $14^{\text {th }}$ Annual Convention of the Society in Salt Lake City, Utah in 1961. That year the U.S. Postal Service issued a stamp commemorating rangelands bearing a picture of the Trailboss. Stars from the CBS TV series, Rawhide, Paul Brinegar and Sheb Wooley and a real horse entertained a packed house at the Annual Banquet in the New House hotel.

On the International level I have served on numerous Committees, served as a Board Member and as Society President in 1970. Two of the several Committees which I have Chaired were the Planning committee in 1965 and 1966 when the recommendation was made to hire a permanent Executive Secretary and move Society Headquarters to Denver, Colorado. The other was the Public Affairs committee in 1982 and 1983 under Presidents Jack Bohning and Gerald Thomas when several important issues were addressed.
During the year I was Society President we reviewed and made in depth comments on every recommendation in the exhaustive Public Land Law Review Commission Report. Our review report was presented to the Commission at a three day National Discussion Forum in Portland, Oregon. Several Board Members, the Executive Secretary and I attended this Forum. The Society's work on this important document was a major effort. All involved felt a sense of accomplishment.

During 1970 the name of the Society was change from the American Society of Range Management to the Society for Range Management. This action was taken following a referendum by the membership.

The Student Organizations were revamped and simplified and Harold Heady's recommendation to create an International Rangelands Congress was approved and became a reality. We also decided to hold the 1972 Annual Convention of the Society in Washington, D.C. an action requiring the President to cast the deciding vote. It turned out to be a wise decision.

Some of my observations and perspectives concerning the Society for Range Management have been expressed earlier. The Society has a firm foundation on which to build a broad based organization that can lend a powerful voice in the proper use and management of the world's grass and forb producing land. Position statements developed by the Society on many of the vital issues affecting these lands are already in place. I firmly believe, however, that inadequate emphasis is placed on values other than domestic livestock grazing. Other values are important, in some situations dominate. I believe emphasis must be given to a broader picture in our actions and discussions.

Few activities in my life have given me more satisfaction and pleasure than my association with the Society for Range Management. The friendships gained, the opportunity to deal with people of diverse opinions and perspectives and the platform the Society has created for the discussion of controversial issues all are dear to my heart. And perhaps most of all, I gain renewed hope for the future of mankind when I witness the enthusiasm of the young people who make up such an important part of the Society for Range Management. 